\title{
How do citizens feel about their water services in the water sector? Evidence from the UK
}

\author{
Kang Tian ${ }^{1,2}$, Zhuo Chen ${ }^{1 *}$ (I) and Han Wang ${ }^{3}$
}

\begin{abstract}
At present, many studies have used social survey methods to explore UK water citizens' perceptions of the water sector's water services, but there are few more targeted and systematic studies. This paper mainly displays the perceptions of UK water citizens on water services in the water sector in recent years and analyses the main reasons for different perceptions and possible strategies. We conduct extensive research from four aspects that are highly related to water services: water citizens' perceptions of the water supply services and technology application (infrastructure construction) provided by the water sector; the state of communication between the water sector and water citizens and their perceptions of water supply management; water citizens' perceptions of the comprehensive utilisation of water resources in the water sector; water citizens' perceptions of the water prices set by the water sector. These discussions aim to discover citizens' perceptions of the water sector and the effects on the public participation mechanism. These insights help attract the water sector's attention so that the public's opinions can genuinely support water policymakers and provide sure support for the water sector to formulate corresponding solutions.
\end{abstract}

Keywords: Perceptions, Water supply services, Technology application, Water supply management, Comprehensive utilisation, Water price

\section{Introduction}

Globally, by 2050, domestic water use is anticipated to increase by $130 \%$ [1]. Faced with rising pressure on the water supply, water companies use a combination of tools to increase water capacity (through water reuse schemes) and decrease demand for water (through motivating customers to change behaviour). Due to the continuous reduction of available freshwater resources, the quality and service level of the water supply is gradually affected $[2,3]$. Although some policies have been formulated to alleviate or reduce the potential risks of water supply, it is anticipated that extensive adaptation measures will still be required to reduce water stresses in urban population

\footnotetext{
*Correspondence: 13803837671@163.com

${ }^{1}$ School of Management and Economics, North China University of Water Resources and Electric Power, Zhengzhou 450046, China

Full list of author information is available at the end of the article
}

centres [4]. The review shows that although the amount of adaptation research that can provide decision support has grown exponentially in the past few decades, there is still a deficit in understanding the specific information that decision-makers require and use when making decisions $[5,6]$. The facts have proved that the lack of decisive communication methods does the work of reducing water consumption very ineffective $[7,8]$ and may even lead to an increase in water consumption as individuals seek to protect their "water rights" [9]. In other words, the water sector needs to promptly communicate with water citizenship on time to understand citizens' perceptions of the water sector. This can provide specific guidelines for the water sector to improve the quality of service and increase the satisfaction of water citizenship.

It is essential to recognise that the water sector in the UK represents a policy context where the institutional enmeshing of commodity-like entities such as 
water are often removed from being entirely managed or governed at the local scale due to marketisation, thus making the operational thinking a complex one [10]. In the UK, a mixture of public-private (Scotland, Northern Ireland), private (England), and employeeowned (Wales) companies provide water, wastewater, and stormwater services under-regulated and nonregulated regimes $[10,11]$. Over 50 million household and non-household consumers in England and Wales receive good-quality water, sanitation, and drainage services. These services are provided by 32 privately owned companies in England and Wales [12]. The sector can be characterised by its high fixed costs, longterm relationships, and limited competition, as well as the extent of financing required [13]. There are many different ways to conceptualise individuals who might be targeted for engagement initiatives. Other research or practice disciplines use different terms and concepts. These include citizens, individuals with a right to access clean water and related services; the public, any individual or group of individuals; consumers, water users who pay for water and related services; and stakeholders, individuals that have an 'interest' in the issue [14, 15]. It also may include those directly or indirectly affected by the issue or those whose interest is personal, financial, moral, or legal. In this review, the term 'water citizenship' will be used inclusively to refer to the public and citizens.

The public's perceptions of the water sector and the services provided by the water sector will directly affect the sustainability of the water supply and the future development of the entire water supply industry. The current water business operation units or organisations have relatively weak external adequate competition pressure, and there is insufficient internal motivation to improve efficiency and service quality. Despite the participation of the Office of Water Services (Ofwat), Drinking Water Inspectorate (DWI), Environment Agency (EA), Natural Resources Wales (NRW), and the newly established Market Operator Services LTD (MOSL), each of the five agencies have a division of labour, which has dramatically improved the overall water service level. However, the status quo of the pluralised internal system regulation and internal management, service efficiency, and service awareness has caused citizen participation to gradually become the top priority of the water sector's planning and management. In trying to identify water-related problems, it is essential to consider the local conditions of citizens, develop cultural-related solutions, and implement appropriate solutions and appropriate interventions to solve the problem [16]. Therefore, the public's perceptions and practical suggestions are incorporated into the water services of the water sector, and the role, status, and benefits of water citizens are emphasised to improve the level of water services.

\section{Materials and methods}

A significant gap in the current literature is the relative lack of long-term research on citizens' perceptions of water services in the water sector from different dimensions and the failure to form a research system on public participation in water services. However, some examples that support widespread changes have been noted. When formulating the water service policy, there are different ways to understand water users. Water users can be regarded as customers who pay for goods through commercial transactions with a certain level of service or as citizens in a political system that recognises water rights [17]. Several studies also emphasise that water user perceptions of water services and water interventions are linked to intervention acceptance and long-term sustainability (e.g. $[18,19])$. The UK water sector has established a public participation mechanism to protect the rights of water citizens from different aspects. Ofwat and DWI issue an annual bulletin to allow the public to quickly obtain water quality information and fully protect the public's right to know. Besides, the UK water sector has formed a remarkable legal document for public participation in water services and will also accept complaints from water users against water companies.

According to the research topic of the paper, all research articles come from Science Net, Scopes Net, JSTOR database and Google Scholar. The keywords are mainly "water supply service or wastewater service", supplemented by "water resource utilisation", "water resource management", "water price", and "technical application" as keywords for advanced search. In addition, it is necessary to screen out articles that are similar to the research topic of "Service Satisfaction with Water Sector". We need to set some other search conditions, and mainly the research area is limited to the UK and articles published in recent years as much as possible. These documents are more representative of the perceptions of modern British citizens on water or wastewater services in the water sector. This study also collected relevant reports and published data issued by water sectors or companies, supplementing information not involved in the literature research.

The identified literature and related reports are used to dig out different research categories using content analysis methods and analyse citizens' perceptions of the services of the water sector according to these categories. The UK Consumer Council for Water (CCW) has launched a survey of citizens' satisfaction with the water sector's services since 2011. With the gradual improvement of surveys and evaluations, water citizens' 
perceptions of the water sector have been demonstrated in water services, wastewater treatment services, communication and consultation, and water charges. Besides, some experts and scholars believe that water resources management and technology applications are also observed indicators of water or water service satisfaction [19-22].

Therefore, this research mainly includes four main aspects. The first relates to water citizens' perceptions of water supply services and technology applications in the water sector. It mainly determines the satisfaction of citizens with the service provided by the water sector and the recognition of the technical application in the water sector. The second aspect is the citizens' perceptions of water supply management in the water sector. It mainly establishes the communication status between the citizens and the water sector and the citizens' perceptions of the management methods and policies in the water sector; the third relates to citizens' perceptions of the comprehensive utilisation of water resources in the water sector. It mainly establishes how citizens feel about wastewater treatment and water reuse practices. The final aspect concerns citizens' perceptions of water supply safety and water prices in the water sector. It establishes the citizens' response to the water price setting in the water sector. These discussions aim to discover citizens' perceptions of the water sector and the effects of the water sector in the public participation mechanism and explore the significant impact of citizens' perceptions of the work of the water sector.

\section{Perceptions of water supply services and technology application in the water sector}

In the UK, water provided by the water sector is a commodity and a service. In addition to the factors that citizens need to consider water quality and water supply safety, an intuitive feeling of citizens in water use is the service provided by the water sector or company, and the citizens have already paid for it. The most crucial service measure to ensure water quality and water supply safety is technology, which is mainly reflected in the use of infrastructure. Therefore, this part mainly summarises the three aspects of water supply service, water infrastructure, and technical support.

\section{Water supply services}

Water supply services mainly include water supply safety, a supply interruption (planned and unplanned), water quality, etc. These services are essentially "public goods". However, because many citizens live in different areas, different water companies that provide services result in different levels of service enjoyed by citizens [23].

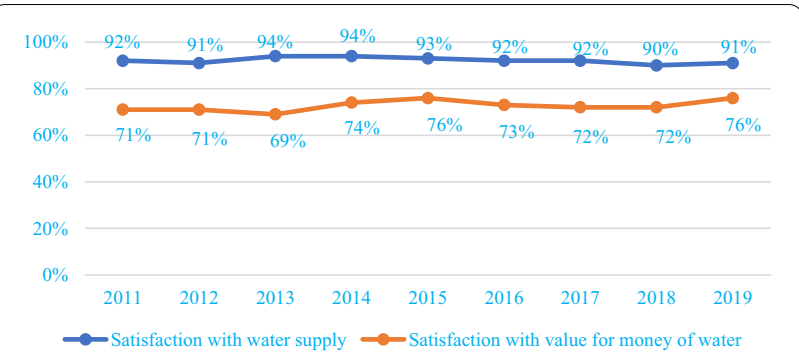

Fig. 1 Overall satisfaction with water and value for money of water (data source from CCW [43]). The rolling 9-year averages are calculated based on the total valid base of weighted data at each time point. The 9-year trends are assessed using the MannKendall method $[119,120]$. The Mann-Kendall analysis is applied to exponentially smooth, transformed data rather than the raw data. The data calculation methods in Figs. 2, 3, and 4 also use this method

Perception affects users' views of water services and their ability to discern that water service interventions are beneficial to health. It also affects the payment, acceptance, and willingness to use water services in the long term [24]. Perceptions are variable, subjective, and based on beliefs and lived experiences that cannot be objectively verified or measured. However, perceptions must be considered because they ultimately manifest in fundamental behaviours and actions [25]. In recent years, the British water sector has been continuously reforming to standardise water supply services, improve the quality of water and wastewater, and raise citizens' positive perceptions of water supply services [26]. Many citizens surveyed said that they felt that the water sector's quality of water services was gradually improving. It can be found from the satisfaction reports published by CCW in recent years, as shown in Fig. 1, even though the number of citizens surveyed by the survey report is limited.

Many water users say that if they have no health problem caused by poor water quality, there is little motivation to change drinking water sources or invest in water services $[27,28]$. Nevertheless, when users receive some innovative services [29], for example, information services [30], consumption simulation [31], smart measurement [32, 33], intelligent control and delegation, roaming and payment, they will agree with the existing innovative service models for water supply and thought this worked well. Whilst the sector has seen a range of service innovations, there is still some cynicism from non-household customers as to whether its use in the water sector will be beneficial or costly and whether regulation will be reintroduced at some future point [29].

International academic research on water supply services shows that the general public (water users) will give priority to the quality of drinking water and the reliability of safe supply (e.g. [34-38]). If the water 
sector guarantees the reliability of the water supply, quality issues will become the first consideration for water users [37]. This result shows that water quality is inherent to the public discussion of public health [38]. CCW investigation showed that $90 \%$ of customers were satisfied with water services (92\% in 2017) and 85\% with sewerage services ( $88 \%$ in 2017); the satisfaction data of England and Wales in the past 9 years are shown in Fig. 1 [39]. The results show that the overall satisfaction is relatively high, but the satisfaction of wastewater services is lower than that of water supply services. However, awareness of Water Sure and Priority Services has increased since 2011, there have been fallen in awareness in 2017 [40]; this also proves that water users lack differences in water service priorities and preferences [37]. These results may lead to the water sector's inability to use feedback from these services to inform their plans and decisions, especially where regulators and stakeholders may review [41]. However, over time, long-term unreliable water supply services can lead to water users' distrust of water companies [42].

\section{Water infrastructure}

The water infrastructure is essentially the embodiment of the technical system, which constitutes the technical structure of the entire water supply system and provides essential functions for water users [44-46]. In Great Britain, the state of the water services infrastructure has been rated B (on a scale of A-E) [47]. The issues concerning poor quality infrastructure and the delivery of infrastructure-related services have continued to elicit high levels of interest [48, 49]. Infrastructure is often thought of as a response to social technology, but it is not just technology. Based on the insights from technical research, the water supply system can be seen as a manifestation of technology, including rules and regulations and cultural norms [50]. Moreover, certain technologies provided by the water sector, such as water meters, allow users to feel their water consumption intuitively, and some families introduce new technologies that will make it more convenient for them to store water in their houses [14]. More and more people are using the Web as an information source. For example, Thames Water provides a large amount of information on joint water equipment and technology on its website; the public has replaced many electrical appliances in their homes after researching this information. Many families also claim that they want more information, not limited to water issues but includes effective water technologies [14].

\section{Technical support}

With the gradual application of advanced technology in the water service system, the public's demands for technology are reflected in its application and convenience. For example, the client proposed to the water company the idea of explaining its water supply in a more straightforward, less technical, and more explicit way to better understand the meaning of its water supply. Scottish Water also realised the application to its business plans $[51,52]$. When the water sector learned that technological progress could circulate water purified using advanced technology was cleaned and purified to a high level and met strict water quality and health standards [44]. As a result, water users have more positive emotions and less negative emotions towards reclaimed water, as well as increase their perception that recycled water has a lower risk and are more willing to support recycling water plans, including increasing the possibility of voting for such plans [53].

The study also proved that the current technical support provided by the water sector is still insufficient to meet the needs of water users. For example, water users have shown tremendous willingness to change their behaviours to conserve water, but water provision technologies and infrastructure are rarely available to support their efforts [14, 44]. Another convenience is about the water users' perceptions of technical maintenance. Some studies mentioned that customers are not optimistic about the regular maintenance of water infrastructure and local spare parts, and local technical reserves to provide fast and high-quality repairs [54, 55]. However, Water UK has responded to the release of the National Infrastructure Strategy in 2020 and increase investment in infrastructure to continue to provide services to its customers and the environment. Because the water company's efforts have also achieved partial results, pipeline leakage has been reduced by $7 \%$ in 2020 and promised to reduce it by half by 2050 .

There has been an awareness of the threat to the climate and environment of the changes caused by population growth and the intensified urbanisation process, which have brought tremendous pressure to existing water supply services, water supply systems (infrastructure, technological products), and sustainable development $[45,46]$. The ability of the water sector to continuously provide safe (reliable) services is constantly being challenged. Water users, even more, expect the water sector to develop new innovative service strategies, invest in facilities and products that are more in line with customers, and further strengthen the water sector's ability to deal with water resources issues. More importantly, these strategies must also be sustainable in response to the changing environment. 
Likely to contact water/sewerage company company if worried about bill

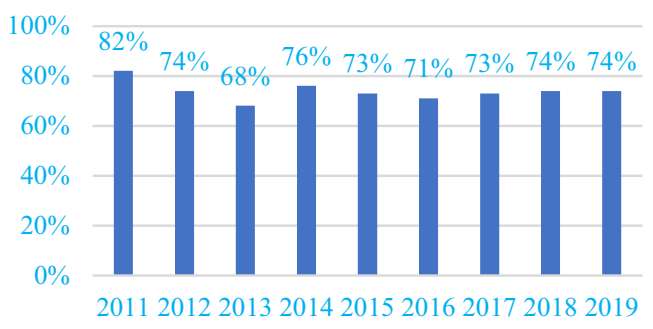

Actual contact with water/sewerage company

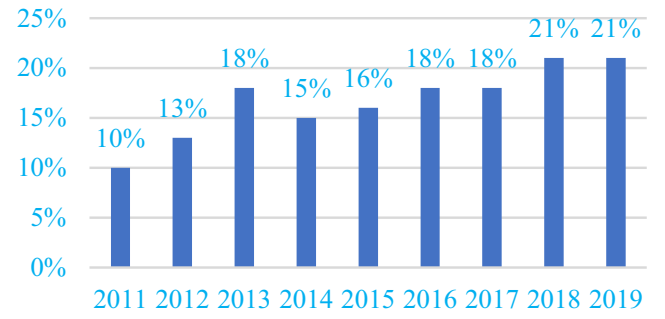

Fig. 2 Likelihood to contact if worried about bill and level of actual contact with water/sewerage company (Data source from CCW [43])

\section{Perceptions of water supply management in the water sector}

Water supply management is the behaviour or activity that the water sector implements management in the water supply process. The most critical participants in the entire water supply management process are citizens. Establishing a good communication relationship between the water sector and citizens, sharing waterrelated information (such as water quality information, billing information, etc.) is very important to improve citizens' satisfaction with services. The water sector must also clarify the water needs of citizens to provide citizens with better water services. In addition, the water sector needs to ensure the necessary emergency management of water supply and can solve the water supply of the citizens in time when encountering sudden water supply problems. This is very important to increase the recognition of the citizens to the water sector. Therefore, this part summarises the three aspects of information communication, water demand management for citizens, and emergency management of the water sector.

\section{Communication of water-related information}

Public support is more than just public awareness or interest in a policy issue. It involves the public taking a positive attitude to communicate and take action, and responses could be exemplified as 'Of course we should do that!' [56]. Public participation is a paradigm that shows trust. According to the research results, it is the main factor affecting the water recycling plant of the water sector [57]. This strategy is a face-to-face communication method that focuses on participating in the opinions of experts and leaders and interacting with the water sector [58].

There is a legal obligation on the water sector in the UK to promote efficient water use, and pressure on water resources means that water companies need to encourage changes in water consumption behaviours. However, there is a lack of information about how UK water companies communicate with the public [59]. A report showing that the percentage of total water company spending used on water resources and efficient communications in the UK $(0.2 \%)$ was much lower than in the EU (1\%), the US (1\%), or Australia (6\%) [60], this also shows that the UK's expenditure on customer communication and water efficiency marketing needs to be improved. It is necessary to move towards actively interacting with customers, mainly focusing on achieving large-scale water reduction. Studies have confirmed that interviewees recognised the need for an ongoing conversation about water in the UK and identified many practices that could support a change in public water consumption, for example, once a water company communicates with water users about drought issues in time, water citizens will always consciously do something to reduce water consumption [59, 61]. Interviewees also believe that the water consumers within groups (e.g. Consumer Association) may be more amenable to communication with the water sector about water risks, arguing that those with a greater connection to water could act as trusted messengers for water risk messages.

However, most water users are only likely to contact the water company or related sector when they are worried about the bill. The CCW's report in 2020 shows that fewer customers say they are likely to contact their water and sewerage company if worried about their bill over the last 9 years in England and Wales. However, when customers do contact, they are increasingly likely to be satisfied [43]; the trend in the past 9 years is shown in Fig. 2. From the data in the figure, in England and Wales, there may be contact with water or sewage companies for billing issues, but the average level of actual contact each year is only about $1 / 5$; there is a connection between water citizens and the water sector needs to be strengthened to obtain more water use information. 
The percentage of consumers concerned about billing problems and contact water or sewage treatment companies has decreased, indicating that water utilities have improved their water billing services.

\section{Water demand management for citizens}

Water users need to keep in touch with the water sector and share information to understand the different situations they may encounter to get more strategic guidance to support the adoption of specific response mechanisms [62]. Only those water users who contact the water sector or company can be satisfied with their treatment, including quality of information, knowledge/professionalism, resolution and kept informed [40]. As the research results of Larbey and Weitkamp [59] show that many water users want to have continuous communication with the water sector because "Once you stop doing this (shortterm), the expected behaviour or expected awareness will disappear." Some other interviewees said they are ignorant of water resources most of the time and hope to communicate throughout the year on water-related issues [59], which can be more aware of water information. As far as water-saving and information feedback are concerned, we can do better and better by knowing more information.

In the desired field, the water sector's supply and demand management is an attempt to reduce water consumption and an attempt to reduce safety and reliability risks and enhance customer service [63]. It is introduced in the introduction that the UK's water sector consists of multiple agencies and companies, a complex system. This complexity may hinder sustainable water management [64]; through research, it is found that the water sector still expects to create conditions to support specific water demand management models. However, the water users interviewed criticised the demand management activities of the water sector and believed that these ideal methods obscure specific ways to improve water efficiency daily [63]. The water sector should focus its management on technological transformation and water-saving proposals [61]. During the interview, Bunney [65] found that people think that finances and resources are limited, and they expect managers to provide the same level of service with fewer resources.

\section{Emergency management of water sector}

Regarding citizens' satisfaction with the water sector's emergency management of water resources, Bunney's ([65]], p. 268) survey results show that most respondents "agree" (50\%) and "strongly agree" (41\%) that local authorities have the responsibility to prepare for emergency management in possible emergencies. The water sector is increasingly using social media to provide customers with relevant basic service information. However, the public realised that the upload of instant information was complex for the water sector to manage, and there was not enough time for participants to understand the emergency and determine how to respond to the emergency ([65], p. 254). For example, from late February to early March 2018, the United Kingdom experienced a long-term low-temperature effect termed the "Beast from the East" by the British media, affecting many parts. During this period, the Web Standards Project (WSP) in the UK actively advised customers on the potential consequences of freezing pipelines in their homes. However, as the temperature rose, WSP was faced with a series of pipe ruptures that have disrupted the centralised water supply of more than 200,000 customers [66]. At least 36,000 people did not have a centralised water supply for more than $24 \mathrm{~h}$, sometimes even more than 5 days 40. Since then, the water sector has made great efforts in emergency management, such as establishing an integrated social network before an emergency, increasing social capital, and providing many advantages for the community and responder organisations [67-70]. Those have helped the water sector maintain emergency management in emergencies to achieve the desired goals.

After reviewing documents, most studies show little or no communication between water citizens and water sectors (e.g. $[10,59,61])$. Some water citizens say that there are limited communication and information, and they need lengthier and more detailed communication to deepen their understanding of water resources. The water sector is also continuously strengthening communication practices $[39,40]$. The perception of water supply and demand management in the water sector is not ideal, and water citizens pay more attention to improving water use efficiency and using fewer resources to obtain better services. The water sector still needs to provide further information sharing and clarification regarding water resources security and macro-management. In water resources emergency management, citizens depend on the water sector, but the ability to deal with emergencies still requires further strengthening.

\section{Perceptions of the comprehensive utilisation of water resources in the water sector}

Comprehensive utilisation of water resources is currently essential for alleviating water shortages in many countries or regions. The key to the comprehensive utilisation of water resources is citizens' perceptions of the reuse of reclaimed water. Citizens' satisfaction with wastewater treatment determines their acceptance of reclaimed water. In addition, seawater desalination and utilisation, rainwater harvesting, and reuse are crucial factors that reflect citizens' perceptions of water or wastewater 


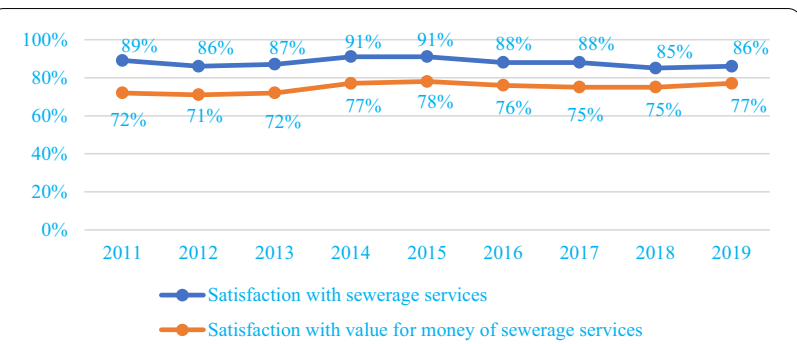

Fig. 3 Overall satisfaction with water services and value for money of sewerage services (data source from CCW [43])

services in the water sector. This part mainly summarises three aspects of comprehensive utilisation of water resources: Seawater desalination and utilisation, rainwater harvesting, and water reuse.

\section{Wastewater treatment satisfaction}

The evidence base of water citizens' preference for wastewater services is relatively small, which has also been confirmed in the research, and there is not much difference in the focus of customers' investment in water and wastewater services [71, 72]. However, the continuous increase in water demand and difficult-to-control pollutants (such as pollutants from agricultural and urban diffusion sources) have made the currently less optimistic ecosystem problems more complicated [73-76]. It has been pointed out that water and wastewater treatment should be further improved and optimised in smaller scattered locations and a few extensive centralised facilities $[77,78]$.

In the UK, the $\mathrm{CCW}$ publishes annually the results of a survey of customers' views on different "water issues" to monitor and motivate the relevant water service sectors. Since 2015, water users' satisfaction with sewerage services has declined, but from the overall data analysis results, the satisfaction rate exceeds $85 \%$. Consumers' satisfaction with the value of sewerage services is lower than their overall satisfaction with them because consumers have paid a specific fee for wastewater services, which may cause some people to have lower satisfaction. However, the results of the past 9 years have shown a gradual upward trend, which also confirms that the water sector has invested more energy and funds in service satisfaction and achieved results [43], see Fig. 3. The increase in satisfaction is driven more by the privatisation system of the water sector, which makes water companies and the water sector more motivated to treat wastewater before it is discharged [79-81]. Many water users are willing to pay the corresponding water fees, providing specific financial support for the water sector for sewage treatment because this is closely related to their lives.
The wastewater treatment process is regulated by law, ${ }^{1}$ which establishes the standards and environmental standards that must be met. Due to factors such as the stricter environmental regulations, the encroachment of residential areas by wastewater treatment plants, generally higher environmental standards, and the increasing expectations of the public of the duties of private water companies, the number of public complaints about wastewater odour has dramatically increased [82]. However, the water sector has adopted many measures in wastewater treatment services, such as the use of advanced technology (e.g. [83, 84]), A membrane bioreactor [85], Constructed wetlands [86]. However, judging from the current state of public satisfaction with wastewater treatment [43], the water sector still needs to improve wastewater treatment facilities, technical means, and management decisions.

\section{Seawater desalination and utilisation and rainwater harvesting}

UK water companies must consult with the public on their water resources plans. The water industry is highly aware of the importance of public awareness of new water sources such as desalination and recycling [87]. However, there are many challenges in seawater desalination and utilisation promotion, mainly whether there are satisfactory services in the desalination and utilisation of seawater, and citizens' opinions will restrict the construction and use of some facilities [88]. Escobar (2010) learned from some investigations and studies, including those in the United Kingdom [89], desalinated water after seawater treatment is considered less risky, and the acceptance level of reclaimed water is lower than that of desalinated water. Escobar also believes that for desalinated water to gain public recognition faster, suppliers must monitor their desalination process and measure the quality of the desalinated water continuously [90]. Dolnicar et al. [91], Fewkes [92] and Warner et al. [93] researched citizens' acceptance and perception of Rainwater Harvesting (RWH); when some participants were asked about rainwater harvesting, they did not realise or were not informed by the relevant authorities whether their houses were partly provided by RWH, "When we moved in, we did not know that the house was installed with RWH systems. However, there are still participants who use the RWH system and have positive experiences in using them and have reported negative experiences [94]; for example, no economic savings were observed.

\footnotetext{
${ }^{1}$ https://www.gov.uk/permits-you-need-for-septic-tanks (General Binding Rules exist in the UK to regulate sewage treatment systems. However, treated wastewater legislation is different in England, Scotland, Wales and Northern Ireland).
} 


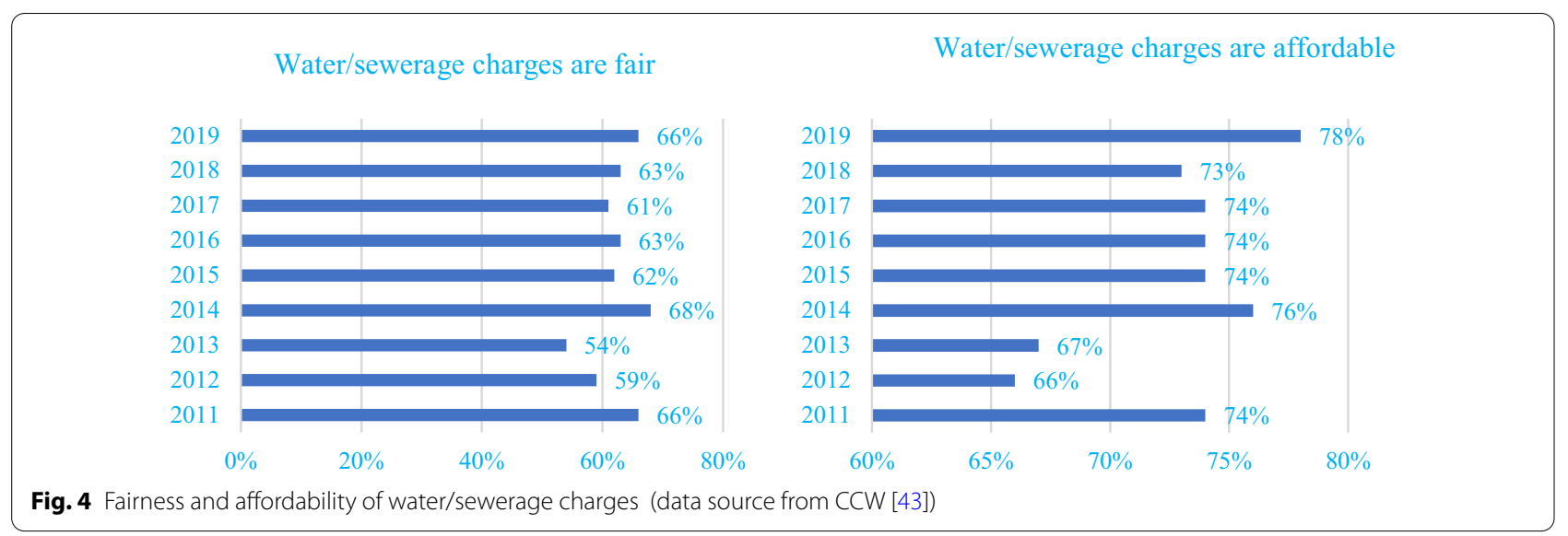

Some people also hope that more consideration will be given to promoting and installing systems that combine multiple uses (such as WC and outdoor uses). The water sector still needs to provide more innovation and support [95-97]. The more significant interaction between system end-users (including home users) and product developers will also increase effectiveness.

\section{Water reuse}

Regarding the literature research on water reuse, this study refers to the literature analysis conducted by Smith [57], which showcases post-millennium evidence and thinking around public responses to water reuse (only refer to the opinions of the UK public on water reuse). Due to the negative response from the public, increasingly projects have failed or been abandoned [98]. Compared with other alternative water supplies (e.g. rainwater harvesting [99]), people often think that the water provided by water reuse programmes is less palatable. Some recorded cases show that water reuse projects were directly reduced or shelved due to public opposition [100]. Similar investigations show contradictory findings. For example, in an opinion survey on household water recycling in the UK [101], water users were reluctant to use reclaimed water alone for garden watering because the chemicals in reclaimed water can harm their plants. On the other hand, because the system's installation costs money and requires a lot of working time, it may not be possible to use the system alone. However, other studies have shown that a willingness by people to reuse water. For example, Jeffrey [102] investigated the internal recycling attitude of 300 participants in England and Wales by focusing on the universal recycling system (water reuse in showers and bathtubs). The results show that if organisations have established reusable standards that are trustworthy, the public will express their willingness to recycle and use them.
According to the above research conclusions, the attitude of most water users to water reuse is that they worry about water quality problems and need to instal and use reclaimed water recovery systems and are unwilling to drink or use reclaimed water to irrigate plants. The key to solving these problems is that the water reuse plan implemented by the water sector and the service facilities provided needs to be further improved and strengthened to improve the quality of reclaimed water continuously. Water citizens can use the treated water with confidence and trust the water sector emotionally as much as possible. Simultaneously, in promoting and using reclaimed water, the water sectors need to provide more relevant information and increase communication to increase the possibility of water users accepting recycled water.

\section{Perceptions of water prices in the water sector}

According to CCW's 2019-2020 annual report, in 2019, 66\% of customers in England and Wales agreed that the fees they paid were fair, and more customers agree that their charges are affordable than fair. The positive perceptions of water consumers in England and Wales on the fairness and affordability of water/sewage charges in the past 9 years are shown in Fig. 4 [43]. Overall, water consumers do not have a high degree of recognition of the fairness of water charges (around 60\%). Still, the trend in recent years has been gradually increasing, indicating that the water sector has also done so in terms of water charges to meet consumer demand worked hard. Simultaneously, with the continuous development of the economy and the improvement of living standards, consumers have a higher and higher proportion of positive perceptions about being able to afford water bills, reaching the highest value in history in 2019.

From the perspective of many researchers, Liu distributed 93 valid questionnaires in the centre of Loughborough Church. The results showed that $2 \%$ think water 
bills are more expensive, 55\% think water bills are set reasonable, and $43 \%$ think water bills are cheap. $61 \%$ of people use water meters to calculate water cost, but the remaining $14 \%$ are unclear about calculating water cost [101]. Due to the limited knowledge of customers about water charges, the extent to which most customers can participate in discussions about investment plans and their implications for customer bills is also limited [103]. Some customers claim that they "have a say in all issues that affect their bills" ([104], p. 10), especially water prices as the main expenditure on their bills. Many water users believe that the water sector needs to meet the actual needs of customers and the reasonableness of pricing, but they do not oppose mandatory measurement or variable price structures [105].

Using high water prices to reduce demand directly is the most common price intervention in the EU [106], despite public opposition [107]. Increasing Block Tariffs (IBT) is the policy proposed by the water sector to achieve price setting. Various research has been conducted on citizens' perceptions of IBT. For example, Gardner [108] surveyed the opinions of UK households on water prices and water consumption. Survey results showed that only $15 \%$ of respondents were willing to check the water price and believed that the water sector needs to understand further the household's understanding of water prices and water use. Most respondents avoided answering questions about IBT and overestimated water prices because of it. From a consumer's point of perception, IBT may cause price confusion, indicating that it is unlikely to work in theory, although this does not rule out the possibility of IBT effectively reducing consumption [109]. It is also necessary to improve the performance of IBT and reduce the possible adverse effects of IBT on unknowing families.

When communicating with water users, the water sector should directly target their users' understanding of tariff structure and consumption, rather than indirectly through bills [108, 109]; many users have expressed doubts about the bill. When water users see a high bill, they may voluntarily give up the cost of services improvement, though others may be willing to pay a certain annual fee as the cost of the water sector to improve the quality of service [110, 111]. In addition to bills, water citizens want a clearer understanding of water prices and payment of water fees, and more information on water price regulation needs to be disclosed [112-114]. In England and Wales, the water sector is regulated under the $\mathrm{RPI}-\mathrm{X}+\mathrm{K}$ (Retail Prices Index $-\mathrm{X}$, where $\mathrm{K}$ is based on capital investment requirements) price cap method [115]. As an economical regulatory agency, Ofwat is responsible for setting the price limit for each company every 5 years. When setting urban water prices, water users believe that assessing determinants is very important for the regulatory agency [116].

Considering the multi-objective environment, the design of water prices is a complex issue, and it is expected to pursue social, political, economic, and environmental goals while simultaneously being easy to implement and transparent to consumers [107]. The water sector, water supply companies, and water users have different expectations of water prices. A single water price tool cannot meet all goals. When considering the current citizens' perceptions of water prices, the water sector should improve the water price mechanism as far as possible based on the needs of multiple parties and the actual situation. Those would enable the water price to positively impact water saving, water supply and distribution efficiency [112] and ensure that citizens can save water within the acceptable water price range.

\section{Discussion}

There has been considerable study from different perspectives into the broad research field of citizens' perceptions of the water sector. As mentioned earlier, although many aspects overlap, the focus of research varies from different perspectives. The literature under review is divided into four sections. The first mainly revolves around the perceptions of water supply services and technology. Since water supply services and infrastructure are the basic guarantees for water citizens, many researchers pay particular attention. The second section is the citizens' perceptions of the communication and management of the water sector. Timely communication and effective water resources management play an essential role in improving work efficiency and promoting the future development of water affairs, thus attracting increasing attention from the water sector and scholars. The focus of the third section is on wastewater treatment and water recycling. The analysis in this area relies mainly on a few influential review articles $[57,117]$. The fourth section is a discussion of water price. Water price is a direct manifestation of water consumption by water citizens. It mainly establishes the related content of water price setting and water price supervision. Table 1 summarises the main research results of the four parts and the shortcomings of the current research.

\section{Conclusions}

This study reviewed the literature related to water citizens' perceptions of water services and the water sector in the UK, mainly from the perspective of service and technology, communication and management, wastewater treatment and water recycling, and water prices. From the research results, the measures taken by the water sector have greatly improved citizens' satisfaction, 


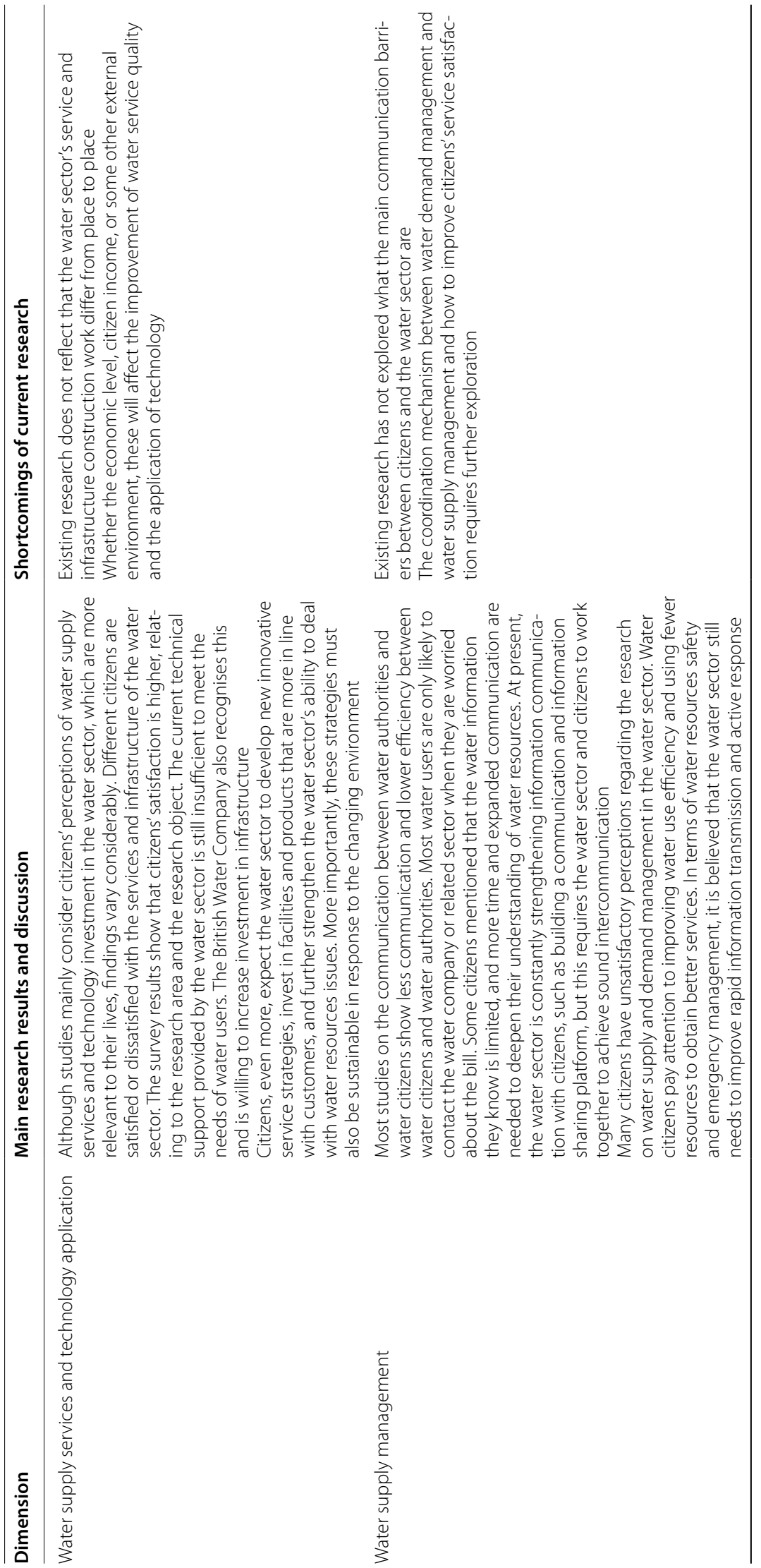




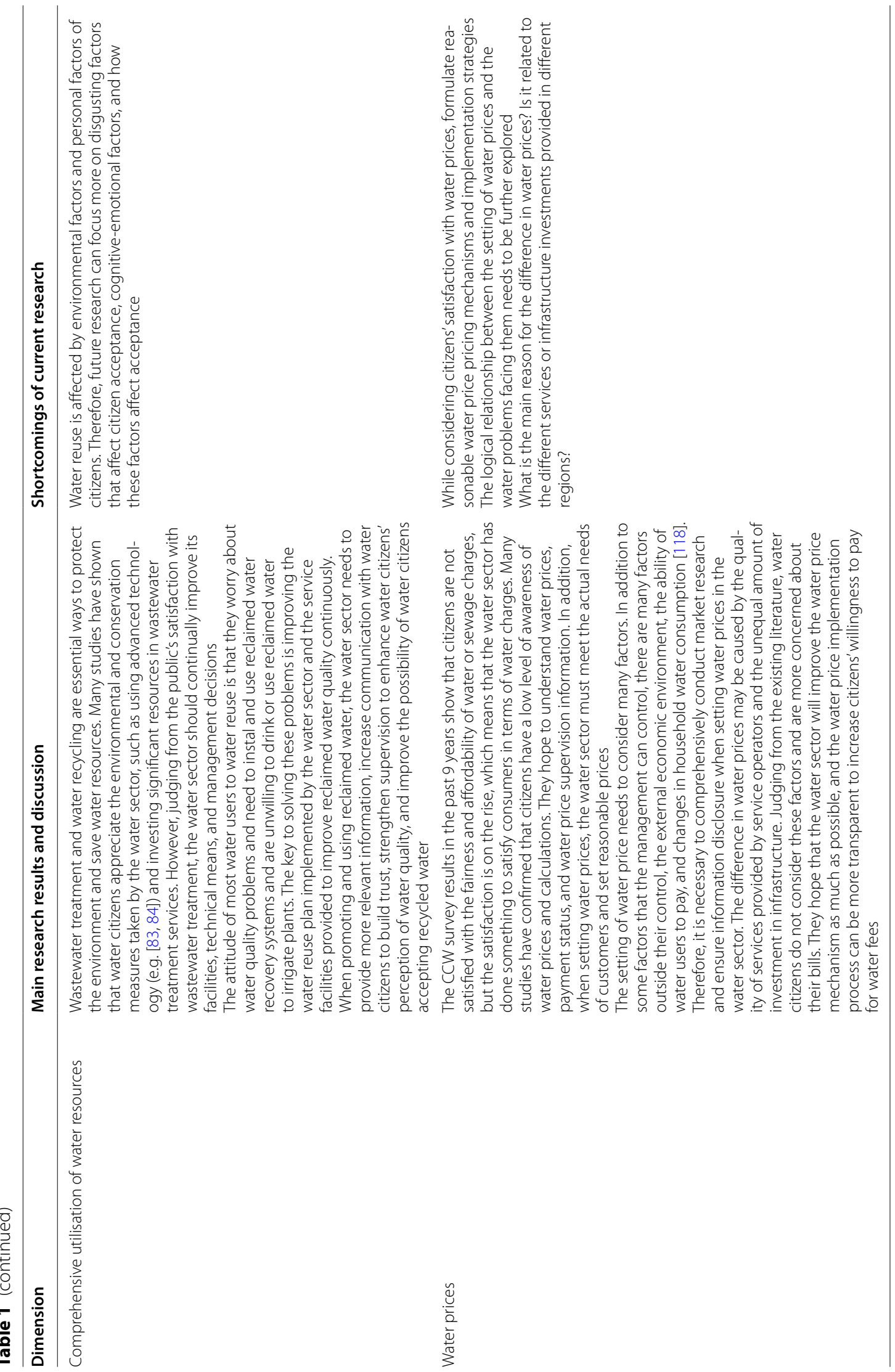


as can be seen from the CCW's annual report "Household customers' perceptions of their water and sewerage services" released by CCW in recent years. However, these data only show generalisations rather than reveal the citizens' perceptions in specific aspects or analyse citizens' perceptions from different angles. The current information related to water or wastewater services cannot change the perceptions of most citizens. There is still much room for improvement in the services provided by the water sector.

The accumulation of research in the past few decades has provided academics with some potential research directions and concerns regarding the water services provided by citizens to the water sector. Nevertheless, it is still necessary to further analyse different levels and regions regarding water supply services, infrastructure construction, wastewater treatment and water recycling, and water prices. It is also essential to pay attention to the possible impacts of the external water work environment and operating mechanisms. In recent years, the perceptions of British citizens have provided significant help to the water sector policy formulation and supervision and evaluation work. The water sector must develop research results on water or wastewater service satisfaction from different perspectives and attract widespread attention so that citizens' perceptions can genuinely support water affairs decision-makers. Those will further improve the service quality of the water sector, continuously increase water citizens' satisfaction with the water sector, promote the harmonious development of the water industry in the true sense, and achieve sustainable development of water resources.

This paper has certain limitations when reviewing different dimensions. When sorting out the focus of research in different dimensions, it is found that the focus of additional research in the same dimension is also inconsistent. For example, regarding the perceptions of wastewater treatment in the water sector, some documents discuss wastewater treatment and water reuse, and some documents discuss wastewater treatment and water management. The same theories have different classifications under different research perspectives, which requires further analysis in future research. In addition, all the evidence sources of the paper come from the United Kingdom, which acquires research data have certain limitations. Whether the perception of water or wastewater services is divided into four dimensions is comprehensive, and whether the research content reflects the forward-looking nature, these need to be further explored based on evidence on a global scale.

\section{Abbreviations}

CCW: Consumer Council for Water; DWI: Drinking Water Inspectorate; EA: Environment Agency; EEA: European Environment Agency; EU: European Union; IBT: Increasing Block Tariffs; ICE: Institution of Civil Engineers; JSTOR: Journal Storage; MOSL: Market Operator Services LTD; NRW: Natural Resources Wales; OECD: Organisation for Economic Cooperation and Development; Ofwat: Office of Water Services; RPI: Retail Prices Index; RWH: Rainwater Harvesting; UK: United Kingdom; WC: Water closet; WSP: Web Standards Project.

\section{Acknowledgements}

Thanks to Dr Heather.Smith from Cranfield University, who provided me with ideas for writing and suggested the paper's final revision. This work was supported by the doctoral student Innovation Fund of North China University of Water Resources and Electric Power.

\section{Authors' contributions}

$\mathrm{KT}$ constructed the overall structure of the review and was responsible for the writing of the manuscript. ZC collected and sorted out some documents, and analysed the data obtained, and was the main contributor to writing the manuscript. She also substantively revised the manuscript. HW polished the English language and expression of the manuscript and put forward essential revisions. All authors read and approved the final manuscript.

\section{Funding}

Not applicable.

Availability of data and materials

All data generated or analysed during this study are included in this published article.

\section{Declarations}

Ethics approval and consent to participate

Not applicable.

Consent for publication

Not applicable.

\section{Competing interests}

The authors declare that they have no competing interests.

\section{Author details}

${ }^{1}$ School of Management and Economics, North China University of Water Resources and Electric Power, Zhengzhou 450046, China. ${ }^{2}$ Cranfield Water Science Institute, Cranfield University, Cranfield MK43 OAL, Bedfordshire, UK. ${ }^{3}$ College of Water Resources, North China University of Water Resources and Electric Power, Zhengzhou 450046, China.

Received: 24 May 2021 Accepted: 3 October 2021

Published online: 18 October 2021

\section{References}

1. OECD 2012 Publishing, \& Organisation for Economic Co-operation and Development Staff (2012) OECD environmental outlook to 2050: the consequences of inaction. OECD Publishing, Paris

2. Jiménez Cisneros BE, Oki T, Arnell NW et al (2014) Freshwater resources. In: Climate change 2014: impacts, adaptation, and vulnerability. Part A: global and sectoral aspects. In: Contribution of working group II to the fifth assessment report of the intergovernmental panel on climate change. Cambridge University Press, Cambridge, United Kingdom and New York, NY, USA, pp 229-269. https://scholarbank.nus.edu.sg/ handle/10635/133175. Accessed 15 Sept 2021.

3. van Vliet MT, Flörke M, Wada Y (2017) Quality matters for water scarcity. Nat Geosci 10(11):800-802. https://doi.org/10.1038/ngeo3047

4. Kundzewicz ZW, Mata LJ, Arnell NW et al (2007) Freshwater resources and their management. In: Parry ML, Canziani OF, Palutikof JP, van der Linden PJ, Hanson CE (eds) Climate change 2007: impacts, adaptation and vulnerability. In: Contribution of working group II to the fourth 
assessment report of the intergovernmental panel on climate change. Cambridge University Press, pp 173-210. http://www.ipcc.ch/ipccr eports/ar4-wg2.htm. Accessed 9 Mar 2021.

5. Berrang-Ford L, Ford JD, Paterson J (2011) Are we adapting to climate change? Glob Environ Chang 21(1):25-33. https://doi.org/10.1016/j. gloenvcha.2010.09.012

6. Hofmann ME, Hinkel J, Wrobel M (2011) Classifying knowledge on climate change impacts, adaptation, and vulnerability in Europe for informing adaptation research and decision-making: a conceptual meta-analysis. Glob Environ Chang 21(3):1106-1116. https://doi.org/10. 1016/j.gloenvcha.2011.03.011

7. Cary JW (2008) Influencing attitudes and changing consumers' household water consumption behaviour. Water Sci Technol Water Supply 8(3):325-330. https://doi.org/10.2166/ws.2008.078

8. Adams DC, Allen D, Borisova T et al (2013) The influence of water attitudes, perceptions, and learning preferences on water-conserving actions. Nat Sci Educ 42(1):114-122. https://doi.org/10.4195/nse.2012. 0027

9. Seyranian V, Sinatra GM, Polikoff MS (2015) Comparing communication strategies for reducing residential water consumption. J Environ Psychol 41:81-90. https://doi.org/10.1016/j.jenvp.2014.11.009

10. Ward S, Meng F, Bunney S et al (2020) Animating inter-organisational resilience communication: a participatory social network analysis of water governance in the UK. Heliyon 6(10):e05069. https://doi.org/10. 1016/j.heliyon.2020.e05069

11. Ofwat (2017) Resilience in the round: building resilience for the future. Crown Copyright (2017). https://www.ofwat.gov.uk/publication/resil ience-in-the-round/. Accessed: 4 Dec 2020

12. Ofwat (2020) Water sector overview. https://www.ofwat.gov.uk/regul ated-companies/ofwat-industry-overview/. Accessed 15 Dec 2020

13. Akintoye A, Renukappa S (2013) The UK water industry: infrastructure, governance and procurement. In: Gunawansa A, Bhullar L (eds) Water governance: an evaluation of alternative architectures. Water governance: an evaluation of alternative architectures, vol 81. Edward Elgar Publishing, Cheltenham, pp 81-114. https://doi.org/10.4337/97817 81006412.00008

14. Doron U, The TH, Haklay M, Bell S (2011) Public engagement with water conservation in London. Water Environ J 25(4):555-562. https://doi.org/ 10.1111/j.1747-6593.2011.00256.x

15. Aslin H, Brown V (2004) Towards whole of community engagement: a practical toolkit. Murray-Darling Basin Commission, Canberra

16. Juran L, Lahiri-Dutt K (2017) Waterscapes in transition: changing uses and perceptions of water in middle-class homes in Kolkata, India. Water Hist 9(4):433-451. https://doi.org/10.1007/s12685-017-0202-5

17. Sharp L (2006) Water demand management in England and Wales: constructions of the domestic water user. J Environ Plan Manage 49(6):869-889. https://doi.org/10.1080/09640560600946933

18. Brown $L E$, Mitchell G, Holden J et al (2010) Priority water research questions as determined by UK practitioners and policymakers. Sci Total Environ 409(2):256-266. https://doi.org/10.1016/j.scitotenv.2010.09.040

19. Ashley RM, Blackwood D, Jowitt P (2004) Sustainable water services: a Procedural Guide (SWARD). IWA Publishing, London

20. Rouse M (2013) J 2013 Institutional governance and regulation of water services. IWA publishing, London

21. Bottasso A, Conti M, Piacenza M, Vannoni D (2011) The appropriateness of the probability assumption for multiproduct technologies: evidence from the English water and sewerage utilities. Int J Prod Econ 130(1):112-117. https://doi.org/10.1016/j.jpe.2010.12.002

22. Barraqué B, Isnard L, Souriau J (2015) How water services manage territories and technologies: History and current trends in developed countries. In: Souriau J (ed) understanding and managing urban water in transition. Springer, Dordrecht, pp 33-59. https://doi.org/10. 1007/978-94-017-9801-3_2

23. Willis K, Sheldon R (2021) Research on customers' willingness-to-pay for service changes in UK water company price reviews 1994-2019. J Environ Econ Policy. https://doi.org/10.1080/21606544.2021.1927850

24. Francis MR, Nagarajan G, Sarkar R, Mohan VR, Kang G, Balraj V (2015) Perception of drinking water safety and factors influencing acceptance and sustainability of a water quality intervention in rural southern India. BMC Public Health 15(1):1-9. https://doi.org/10.1186/ s12889-015-1974-0
25. Sherry J, Juran L, Kolivras KN, Krometis LAH, Ling EJ (2019) Perceptions of water services and innovations to improve water services in Tanzania. Public Works Manag Policy 24(3):260-283. https://doi.org/ 10.1177/1087724X18815486

26. Byatt I (2013) The regulation of water services in the UK. Utilities Policy 24:3-10. https://doi.org/10.1016/j.jup.2012.07.003

27. de França DM (2010) Factors influencing public perception of drinking water quality. Water Policy 12(1):1-19. https://doi.org/10.2166/ wp.2009.051

28. Juran L, MacDonald MC (2014) An assessment of boiling as a method of household water treatment in South India. J Water Health 12(4):791-802. https://doi.org/10.2166/wh.2014.010

29. Ward $S$, Brown $S$, Burton A et al (2016) Water sector service innovation: what, where and who? Br J Environ Clim Change 6(3):216-226. https://doi.org/10.9734/BJECC/2016/23730

30. Goodall JL, Horsburgh JS, Whiteaker TL et al (2008) A first approach to web services for the National Water Information System. Environ Model Softw 23(4):404-411. https://doi.org/10.1016/j.envsoft.2007. 01.005

31. Santos M, Borges A, Carneiro D, Ferreira F (2020) September Detection analysis of breaks in water consumption patterns: a simulation study. In: VII workshop on computational data analysis computational data analysis and numerical methods and numerical methods, p 111.

32. Ribeiro R, Loureiro D, Barateiro J et al (2015) Framework for technical evaluation of decision support systems based on water-smart metering: the iWIDGET case. Procedia Eng 119:1348-1355. https://doi.org/10. 1016/j.proeng.2015.08.976

33. Boyle T, Giurco D, Mukheibir P et al (2013) Intelligent metering for urban water: a review. Water 5(3):1052-1081. https://doi.org/10.3390/w5031 052

34. Nowicki S, Koehler J, Charles KJ (2020) Including water quality monitoring in rural water services: why safe water requires challenging the quantity versus quality dichotomy. NPJ Clean Water 3(1):1-9. https:// doi.org/10.1038/s41545-020-0062-x

35. Tussupova K, Berndtsson R, Bramryd T, Beisenova R (2015) Investigating willingness to pay to improve water supply services: application of contingent valuation method. Water 7(6):3024-3039. https://doi.org/10. 3390/w7063024

36. Edition F (2011) Guidelines for drinking-water quality. WHO Chronicle 38(4):104-108. https://doi.org/10.1016/0035-9203(84)90051-8

37. Chenoweth J, Barnett J, Capelo's T et al (2010) Comparison of consumer attitudes between Cyprus and Latvia: an evaluation of effect of setting on consumer preferences in the water industry. Water Resour Manage 24(15):4339-4358. https://doi.org/10.1007/s11269-010-9662-4

38. Kelay T, Lundehn C, Vloerbergh I et al (2008) Final report: stakeholder interviews. Techneau Report

39. Consumer Council for Water (CCW) (2019) Water Matters-household customers'views of their water and sewerage services 2018. https:// www.ccwater.org.uk/wp-content/uploads/2019/07/Water-MattersHighlights-Report.pdf. Accessed 8 Apr 2021

40. Consumer Council for Water (CCW) (2018) Water matters: household customers'views of their water and sewerage services 2017. https:// www.ccwater.org.uk/wp-content/uploads/2018/07/Water-MattersHighlights-Report-2017.pdf. Accessed 4 Apr 2021

41. Sayles R (2015) Customer contributions to water sector planning and decision-making in England and Wales (Doctoral dissertation, Cranfield University).

42. Major B, Suhrcke M, Hunter PR (2016) How do households respond to unreliable water supplies? A systematic review. Int J Environ Res Public Health 13(12):1222. https://doi.org/10.3390/ijerph13121222

43. Consumer Council for Water (CCW) (2020) Water matters: household customers'views of their water and sewerage services 2019-2020. https://www.ccwater.org.uk. Accessed 5 Apr 2021

44. Bell S (2015) Renegotiating urban water. Progr Plan 96:1-28. https://doi. org/10.1016/j.progress.2013.09.001

45. Butler D, Ward S, Sweetapple C et al (2017) Reliable, resilient and sustainable water management: the Safe \& SuRe approach. Glob Chall 1(1):63-77. https://doi.org/10.1002/gch2.1010 
46. Butler D, Farmani R, Fu G et al (2014) A new approach to urban water management: safe and sure. Procedia Eng 89:347-354. https://doi.org/ 10.1016/j.proeng.2014.11.198

47. ICE (Institution of Civil Engineers) (2010) The state of the nation: infrastructure 2010. ICE, London

48. Treasury HMS, UK I (2010) Infrastructure cost review: main report. HM Treasury and Infrastructure UK, London

49. Hukka JJ, Katko TS (2015) Appropriate pricing policy needed worldwide for improving water services infrastructure. J Am Water Works Assoc 107(1):E37-E46. https://doi.org/10.5942/jawwa.2015.107.0007

50. Obertreis J, Moss T, Mollinga PP, Bichsel C (2016) Water, infrastructure and political rule: introduction to the special issue. Water Altern 9(2):168-181

51. Littlechild S, Mountain B (2015) Customer engagement methodologies in water price setting: experience in England and Wales and Scotland, and possible application to Victoria. A Paper for the Essential Services Commission of Victoria.

52. Alegre H, Baptista JM, Cabrera J et al (2016) 2016 Performance indicators for water supply services. IWA Publishing, London

53. Fielding KS, Roiko AH (2014) Providing information promotes greater public support for recycled potable water. Water Res 61:86-96. https:// doi.org/10.1016/j.watres.2014.05.002

54. Colin J (1999) VLOM for rural water supply: lessons from experience, WELL: water and environmental health at London and Loughborough. WELL Study, Task, No. 162.

55. Carter RC, Harvey E, Casey V (2010) November User financing of rural handpump water services. In: Paper presented at the IRC symposium: 'pumps, pipes and promises: costs, finances and accountability for sustainable WASH Services' in The Hague, The Netherlands, 16-18 November 2010.

56. KU Work Group for Community Health and Development (2014) Chapter 4, Section 3: gaining public support for addressing community health and development issues. Lawrence, KS: University of Kansas. https://ctb.ku.edu/en/table-of-contents/assessment/getting-issues-onthe-public-agenda/gain-public-support/main. Accessed 4 Feb 2021

57. Smith HM, Brouwer S, Jeffrey P, Frijns J (2018) Public responses to water reuse - understanding the evidence. J Environ Manage 207:43-50. https://doi.org/10.1016/j.jenvman.2017.11.021

58. Dean A, Fielding K, Newton F, Ross H (2016) Community engagement in the water sector: an outcome-focused review of different engagement approaches. Cooperative Research Centre for Water Sensitive Cities Ltd. https://watersensitivecities.org.au/wp-content/uploads/2016/ 05/TMR_A2-3_CommunityEngagementWaterSector-1.pdf. Accessed 14 Mar 2021

59. Larbey R, Weitkamp E (2020) Water scarcity communication in the UK: learning from water company communications following the 2018 heatwave. Front Environ Sci 8:578423. https://doi.org/10.3389/fenvs. 2020.578423

60. Lewis H, Gallagher E, Burton A, Russell N (2018) How much do water companies spend on customer engagement in the UK and internationally? London: Waterwise. https://www.waterwise.org.uk/wp-content/ uploads/2018/12/International-Customer-Engagement-Report_Final 2018.pdf. Accessed 21 Dec 2020

61. Orr P, Papadopoulou L, Twigger-Ross C et al (2018) Water efficiency and behaviour change rapid evidence assessment (REA). Final Report WT1562, project 8. London: DEFRA.

62. Cotterill S, Bunney S, Lawson E et al (2020) COVID-19 and the water sector: understanding impact, preparedness and resilience in the UK through a sector-wide survey. Water Environ J 34(4):715-728. https:// doi.org/10.1111/wej.12649

63. Holohan C, Browne AL (2018) Reimagining spaces of innovation for water efficiency and demand management: an exploration of professional practices in the English water sector. Water Altern 11(3):957-978

64. Pitt M (2008) Learning lessons from the 2007 floods. Pitt Review. Cabinet Office, London

65. Bunney S (2019) Building resilience in the UK water sector: a systemsbased approach to emergency management (Doctoral dissertation, University of Exeter)

66. Ofwat (2018) Ofwat: out in the cold: water companies'response to the 'Beast from the East'. https://www.ofwat.gov.uk. Accessed 24 Oct 2020
67. Fox, Andrew and Wilson, Geoff and Essex, Stephen, Community-Institution Social Capital (CISC), Flood Risk and Resilience: Lessons from South Devon, UK (2016) Available at SSRN https://ssrn.com/abstract=27895 88. Accessed 4 Nov 2020

68. McEwen L, Krause F, Hansen JG, Jones O (2012) July Flood histories, flood memories and informal flood knowledge in the development of community resilience to future flood risk. In: BHS eleventh national symposium, hydrology for a changing world, Dundee, pp 9-11. https:// doi.org/10.7558/bhs.2012.ns34

69. McGuinness M, Johnson N (2014) Exploiting social capital and pathdependent resources for organisational resilience: preliminary findings from a study on flooding. Procedia Econ Fin 18(1):447-455. https://doi. org/10.1016/S2212-5671(14)00962-9

70. Forrest S, Trell EM, Woltjer J (2017) Flood groups in England: governance arrangements and contribution to flood resilience. In: Trell EM, Restemeyer B, Bakema M, Van Hoven B (eds) Governing for resilience in vulnerable places. Routledge, Abingdon, pp 92-115

71. Arthur S, Crow H, Karikas N (2009) Including public perception data in evaluating the consequences of sewerage derived urban flooding. Water Sci Technol 60(1):231-242. https://doi.org/10.2166/wst.2009.334

72. Consumer Council for Water (CCW) (2014) Water Matters: Household customers'views on their water and sewerage services 2013. http:// www.ccwater.org.uk/wp-content/uploads/2014/05/Water-Mattershou sehold-customers-views-on-their-water-and-sewerage-services-2013. pdf. Accessed 21 Feb 2021

73. Acreman M, Dunbar M, Hannaford J et al (2008) Developing environmental standards for abstractions from UK rivers to implement the EU Water Framework Directive. Hydrol Sci J 53(6):1105-1120. https://doi. org/10.1623/hysj.53.6.1105

74. Environment Agency (2009) Water for people and the environment: water resources strategy for England and Wales. https://webarchive. nationalarchives.gov.uk/20140328161417/http://cdn.environmentagency.gov.uk/geho0309bpkx-e-e.pdf. Accessed 14 Mar 2021

75. Crabtree B, Kelly S, Green H et al (2009) Water Framework Directive catchment planning: a case study apportioning loads and assessing environmental benefits of programme of measures. Water Sci Technol 59(3):407-416. https://doi.org/10.2166/wst.2009.875

76. Scotland N (2009) The river basin management plan for the Scotland river basin district 2009-2015. The Scottish Government. https://www. sepa.org.uk/media/37609/scotland_rbmp_chapter1.pdf. Accessed 19 Dec 2020

77. Burkhard R, Deletic A, Craig A (2000) Techniques for water and wastewater management: a review of techniques and their integration in planning. Urban Water 2(3):197-221. https://doi.org/10.1016/S14620758(00)00056-X

78. Makropoulos CK, Butler D (2010) Distributed water infrastructure for sustainable communities. Water Resour Manage 24(11):2795-2816. https://doi.org/10.1007/s11269-010-9580-5

79. Byatt I (2004) Managing water for the future: the case of England and Wales. Manag Water Resour Past present. https://doi.org/10.1093/oso/ 9780199267644.001.0001

80. Windahl C (2006) Suppliers in the privatised UK wastewater market and their possible moves towards integrated solutions. Water Policy 8(6):559-572. https://doi.org/10.2166/wp.2006.056

81. Spiller M, Mclntosh BS, Seaton RA, Jeffrey PJ (2012) An organisational innovation perspective on change in water and wastewater systemsthe implementation of the Water Framework Directive in England and Wales. Urban Water J 9(2):113-128. https://doi.org/10.1080/1573062X. 2011.652129

82. Stuetz RM, Frechen FB (eds) (2001) Odours in wastewater treatment: measurement, modelling and control. IWA Publishing, London

83. Jefferson B, Laine A, Parsons S et al (2000) Technologies for domestic wastewater recycling. Urban Water 1(4):285-292. https://doi.org/10. 1016/S1462-0758(00)00030-3

84. Curtis TP (2010) Low-energy wastewater treatment: strategies and technologies. In: Mitchell R, Gu JD (eds) Environmental microbiology, 2nd edn. Hoboken, Wiley-Blackwell

85. Alibardi L, Vale P, Fernández YB (2021) Full-scale trials to achieve low total phosphorus in effluents from sewage treatment works. J Water Process Eng 40(1-3):101981. https://doi.org/10.1016/j.jwpe.2021. 101981 
86. Khomenko O, Dotro G, Jefferson B et al (2019) Influence of sludge layer properties on the hydraulic behaviour of gravel-based vertical flow constructed wetlands for primary treatment of sewage. Sci Total Environ 691:1137-1143. https://doi.org/10.1016/j.scitotenv.2019.07.121

87. Bell S, Aitken V (2008) The socio-technology of indirect potable water reuse. Water Sci Technol Water Supply 8(4):441-448. https://doi.org/10. 2166/ws.2008.104

88. Farahani MHDA, Vatanpour V, Taheri A (eds) (2020) Desalination: challenges and opportunities. IntechOpen, London

89. Jeffery P (2001) Understanding public receptivity issues regarding 'in-house water recycling. Results from a UK Survey, Unpublished Manuscript, Cranefield University

90. Escobar IC (2010) Conclusion: a summary of challenges still facing desalination and water reuse. Sustain Sci Eng 2:389-397. https://doi. org/10.1016/S1871-2711(09)00214-1

91. Dolnicar S, Hurlimann A, Grün B (2011) What affects public acceptance of recycled and desalinated water? Water Res 45(2):933-943. https:// doi.org/10.1016/j.watres.2010.09.030

92. Fewkes A (2012) A review of rainwater harvesting in the UK. Struct Surv 30(2):174-194. https://doi.org/10.1108/02630801211228761

93. Warner D, Lewis K, Tzilivakis J (2019) Stormwater harvesting and flood

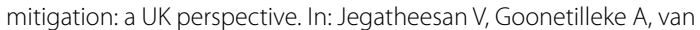
Leeuwen J, Kandasamy J, Warner D, Myers B, Bhuiyan M, Spence K, Parker G (eds) Urban stormwater and flood management: enhancing the liveability of cities, applied environmental science and engineering for a sustainable future. Springer International Publishing, Cham, pp 29-47

94. Melville-Shreeve P, Ward S, Butler D (2016) Rainwater harvesting typologies for UK houses: a multi-criteria analysis of system configurations. Water 8(4):129. https://doi.org/10.3390/w8040129

95. Ward S (2010) Rainwater harvesting in the UK.: a Strategic framework to enable the transition from novel to mainstream (Doctoral dissertation, University of Exeter)

96. Parkes C, Kershaw H, Hart J et al (2010) Energy and carbon implications of rainwater harvesting and greywater recycling. Final Report, Science Project Number: SC090018, Environment Agency, Bristol. http://publi cations.environment-agency.gov.uk/pdf/SCHO0610BSMQ-e-e.pdf. Accessed 3 Apr 2021

97. Ward S, Barr S, Butler D, Memon FA (2012) Rainwater harvesting in the UK: Socio-technical theory and practice. Technol Forecast Soc Chang 79(7):1354-1361

98. Khan SJ, Gerrard LE (2006) Stakeholder communications for successful water reuse operations. Desalination 187(1-3):191-202. https://doi.org/ 10.1016/j.desal.2005.04.079

99. Fielding KS, Spinks A, Russell S et al (2013) An experimental test of voluntary strategies to promote urban water demand management. J Environ Manage 114:343-351. https://doi.org/10.1016/j.jenvman.2012. 10.027

100. Aitken V, Bell S, Hills S, Rees L (2014) Public acceptability of indirect potable water reuse in the south-east of England. Water Sci Technol Water Supply 14(5):875-885. https://doi.org/10.2166/ws.2014.051

101. Liu S (2018) The reuse of greywater for domestic garden irrigation in the UK (Doctoral dissertation, Loughborough University)

102. Jeffrey P (2002) Public attitudes to In-House water recycling in England and wales. Water Environ J 16(3):214-217. https://doi.org/10.1111/j. 1747-6593.2002.tb00397.x

103. Peacock PJ (2014) See on this and other issues the Covering Letter from Peter J Peacock, Chairman of the Customer Forum, to WICS re the agreement between the Forum and Scottish Water, 30 Jan 2014, published in WICS, The Strategic Review of Charges 2015-21, Draft Determination, 20 Mar 2014, pp 73-77

104. Ofwat (2012) Involving customers in price-setting - Ofwat's custome engagement policy statement. https://www.ofwat.gov.uk. Accessed Apr 2021

105. Sharpe RA, Osborne NJ, Skerratt G (2015) Household water efficiency strategies in Cornwall, SW of England. Water Environ J 29(4):457-473. https://doi.org/10.1111/wej.12150

106. European Environment Agency (2017) Water management in Europe: Price and non-price approaches to water conservation. https://www. eea.europa.eu/publications/water-management-in-europe-price/ water-management-in-europe.pdf. Accessed 4 Apr 2021

107. Lu L, Deller D, Hviid M (2019) Price and behavioural signals to encourage household water conservation: Implications for the UK. Water Resour Manage 33(2):475-491. https://doi.org/10.1007/ s11269-018-2133-z

108. Gardner K (2010) Residential water demand modelling and behavioural economics (Doctoral dissertation, University of East Anglia)

109. Lu L, Deller D, Hviid M (2017) Price and behavioural signals to encourage water conservation: a Report to Anglian Water. United Kingdom: Centre for Competition Policy, University of East Anglia, Norfolk. https:// ualresearchonline.arts.ac.uk/id/eprint/14990/. Accessed 16 Apr 2021.

110. Willis KG, Scarpa R, Acutt M (2005) Assessing water company customer preferences and willingness to pay for service improvements: a stated choice analysis. Water Resour Res 41:W02019. https://doi.org/10.1029/ 2004WR003277

111. Solino M, Joyce J, Farizo B (2013) Improving water quality in England and Wales: local endowments and willingness to pay. Int J Environ Res (IJER) 7(3):623-632. https://doi.org/10.1080/13698575.2013.796343

112. Rogers P, De Silva R, Bhatia R (2002) Water is an economic good: How to use prices to promote equity, efficiency, and sustainability. Water Policy 4(1):1-17. https://doi.org/10.1016/S1366-7017(02)00004-1

113. Hanley N, Barbier EB, Barbier E (2009) Pricing nature: cost-benefit analysis and environmental policy. Edward Elgar Publishing, London

114. Al'Afghani MM (2009) The transparency agenda in water utilities regulation and the role of freedom of information: England and Jakarta case studies. J Water Law 20(2-3):129-143

115. Saal DS, Reid S (2004) Estimating opex productivity growth in English and welsh water and sewerage companies 1993-2003. Research paper 0434 Aston Business School, Ashton University

116. Molinos-Senante M, Porcher S, Maziotis A (2017) Impact of regulation on English and Welsh water-only companies: an input-distance function approach. Environ Sci Pollut Res 24(20):16994-17005. https://doi. org/10.1007/s11356-017-9345-2

117. Hartley TW (2006) Public perception and participation in water reuse. Desalination 187(1-3):115-126. https://doi.org/10.1016/j.desal.2005.04. 072

118. González-Gómez F, García-Rubio MA (2018) Prices and ownership in the water urban supply: a critical review. Urban Water J 15(3):259-268. https://doi.org/10.1080/1573062X.2018.1436187

119. Mann HB (1945) Nonparametric tests against trend. Econometr J Econometr Soc. https://doi.org/10.2307/1907187

120. Kendall K (1975) Thin-film peeling-the elastic term. J Phys D Appl Phys 8(13):1449. https://doi.org/10.1088/0022-3727/8/13/005

\section{Publisher's Note}

Springer Nature remains neutral with regard to jurisdictional claims in published maps and institutional affiliations. 